\title{
Consumer society: Its definitions and its Christian criticism
}

\begin{tabular}{|c|c|}
\hline \multicolumn{2}{|c|}{$\begin{array}{l}\text { Author: } \\
\text { Piotr Kopiec }\end{array}$} \\
\hline $\begin{array}{l}\text { Affiliations: } \\
{ }^{1} \text { Ecumenical In } \\
\text { Paul II Catholi } \\
\text { in Lublin, Lubl }\end{array}$ & $\begin{array}{l}\text { stitute, John } \\
\text { University } \\
\text { n, Poland }\end{array}$ \\
\hline $\begin{array}{l}{ }^{2} \text { Department } \\
\text { Testament Stu } \\
\text { of Theology ar } \\
\text { University of } \\
\text { Pretoria, Sout }\end{array}$ & $\begin{array}{l}\text { f New } \\
\text { dies, Faculty } \\
\text { d Religion, } \\
\text { retoria, } \\
\text { Africa }\end{array}$ \\
\hline $\begin{array}{l}\text { Research Proje } \\
\text { Project Leade } \\
\text { Aarde (D) } \\
\text { Project Numb }\end{array}$ & $\begin{array}{l}\text { ct Registration: } \\
\text { r: A.G. van } \\
\text { er: } 2334682\end{array}$ \\
\hline $\begin{array}{l}\text { Description: } \\
\text { This research } \\
\text { research proje } \\
\text { Theology and } \\
\text { directed by Pr } \\
\text { van Aarde, Po } \\
\text { Professor and } \\
\text { Research Fello } \\
\text { Office, Faculty } \\
\text { and Religion, } \\
\text { Pretoria. }\end{array}$ & $\begin{array}{l}\text { s part of the } \\
\text { ct, 'Biblical } \\
\text { Hermeneutics', } \\
\text { of. Dr Andries } \\
\text { t Retirement } \\
\text { Senior } \\
\text { w in the Dean's } \\
\text { of Theology } \\
\text { Jniversity of }\end{array}$ \\
\hline $\begin{array}{l}\text { Correspondin } \\
\text { Piotr Kopiec, } \\
\text { petrko@kul.pl }\end{array}$ & guthor: \\
\hline $\begin{array}{l}\text { Dates: } \\
\text { Received: } 28 \\
\text { Accepted: } 24 \\
\text { Published: } 17\end{array}$ & $\begin{array}{l}\text { Jov. } 2019 \\
\text { Apr. } 2020 \\
\text { Sept. } 2020\end{array}$ \\
\hline $\begin{array}{l}\text { How to cite th } \\
\text { Kopiec, P., } 202 \\
\text { society: Its de } \\
\text { Christian critic } \\
\text { Teologiese Stu } \\
\text { Theological St } \\
\text { a5910. https:/ } \\
\text { 10.4102/hts.v }\end{array}$ & $\begin{array}{l}\text { is article: } \\
0 \text {, 'Consumer } \\
\text { initions and its } \\
\text { ism', HTS } \\
\text { dies/ } \\
\text { udies 76(3), } \\
\text { /doi.org/ } \\
76 i 3.5910\end{array}$ \\
\hline $\begin{array}{l}\text { Copyright: } \\
\text { (C) 2020. The A } \\
\text { Licensee: AOS } \\
\text { is licensed unc } \\
\text { Creative Comr } \\
\text { Attribution Lic }\end{array}$ & $\begin{array}{l}\text { uthors. } \\
\text { IS. This work } \\
\text { ler the } \\
\text { nons } \\
\text { ense. }\end{array}$ \\
\hline Read online: & \\
\hline 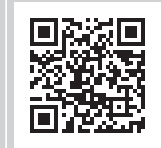 & $\begin{array}{l}\text { Scan this QR } \\
\text { code with your } \\
\text { smart phone or } \\
\text { mobile device } \\
\text { to read online. }\end{array}$ \\
\hline
\end{tabular}

Except for some economists, who think about the consumer society as a way to the political stability and economic progress, the philosophical and sociological view on consumptionism and consumer society is predominantly pejorative. Depending on their axiological starting points, theorists of consumptionism stress its destroying forces for societies, like social idleness, an implosion of social institutions, deepening of social divisions and social exclusion and, last but not least, ecocide. Criticism of the consumer society is also of growing significance for the theological agenda of various Christian Churches and the teaching of ecumenical organizations like the World Council of Churches. The article aims to summarise different approaches to consumptionism and its definitions, which are ordered in two categories: analytical and historical. It also discusses the teaching of Pope Francis, who contributes to the theological perspective of the criticism of the consumer society and focuses on the term of anthropological error as a hermeneutical instrument of this criticism. This task requires employing two main research methods: analysis of selected and relevant literature and synthesising exposition of the results of research. The discourse consists of two parts. The first one presents the term of consumptionism and highlights the scope of discussions on the definitions of this phenomenon. The second demonstrates the Christian interpretation of the problem. The first and the second chapters create a hermeneutical background to the third one; they even might be regarded as its contextualisation. The theological critique of consumer society contributes to the interdisciplinary theory of consumptionism.

Contribution: The theological critique of consumer society contributes to the interdisciplinary theory of consumptionism. It also shows how theology might refer to social studies. Such a juxtaposition of the theological and sociological fields of reflection converges with the focus and scope of the journal to promote multidisciplinary aspects of studies in the general theological area.

Keywords: consumptionism; consumer society; anthropological error; throwaway society; homo consumens.

\section{Introduction}

The narrative of the 'Consumer Society' is one of the dominant debates of contemporary economists, philosophers, sociologists, theologians, and other social researchers on politics, economics, society and culture. The notion of consumptionism has become in recent decades a sort of sociological elementary particle, a word which is used in everyday language and sometimes automatically. In its strictest meaning, the term belongs to economic methodology and therefore does not require an axiological assessment. Yet, for several decades, the category of consumption and its derivatives has been moving far beyond economics and is beginning to be used in varied interdisciplinary descriptions of reality.

Certainly there are few notions that would be defined and interpreted so ambiguously. For some, and depending on adopted axiological foundations, consumptionism may be assumed as a desirable for the social order insofar as it allows and helps modern society to realise its economic functions. For others, it is a purely technical notion that belongs to economics. However, for the majority of its exponents, it is a pejorative word which is analogous to the picture of steadily degrading society, in which moral values are being replaced by the values of consumption. Therefore it is defined in a harshly critical way.

Furthermore, the term of consumptionism is deeply political, making its objective analysis difficult. It is embedded in the post-Marxist, leftist discourse (Firat 2017), where it is regarded as the tool of subjugation of deprived or excluded social groups by the groups of powers, 
both political-economic and cultural. It became a primary concept in the opinions of ecologists who discerned its influence on the spread of egoistical attitudes that destroy natural environment (Sagoff 1998). Also, it is being criticised by theologians of different religions and denominations, who consider it a push factor of an ideational vacuity. As an instrument of political debates and confrontations, it is often purposely distorted and reduced, and the scope of its meaning is extended. Such political involvement and different axiological approaches inevitably mean that criticism of consumptionism is ambiguous. Not only its individual observers but also particular political and ideological groups emphasise different destructive effects. This seems to be another crucial factor that hinders its interpretation.

Christian theologians of different denominations also endeavour to partake in the interdisciplinary debate on consumptionism. This must appear only a little surprising for anyone who attends Sunday worship and listens to homilies. Yet the arguments applied in the everyday church narrative sometimes trivialise and simplify the problem by reducing it to a purely moral question. The theological thinking about consumptionism must correspond to the deep philosophical mulling over the nature of the phenomenon, especially since the Church (churches) wants to be a credible and reliable voice in the discussion of the consumer society. Thus, Christian teaching requires a solid theological research and clear theological statements that consider and acknowledge various arguments arising from different axiological and epistemological approaches.

The article consists of two parts. The first one presents the term of consumptionism and highlights the scope of discussions on the definitions of this phenomenon. The second demonstrates the Christian interpretation of the problem. Therefore, the first and the second parts create a hermeneutical background to the conclusion, and may even be regarded as its contextualisation. The article takes into consideration the teaching of Pope Francis as the theological example of the Christian criticism of consumptionism. It must also be stressed that in the text, the notions of both consumptionism and the consumer society are employed interchangeably. Their differentiation is obvious, but it is not relevant in light of the main purpose of the article.

\section{Analytical definitions of consumptionism}

The notion of consumptionism was introduced to everyday language by American journalist Samuel Strauss in the 1920s. When describing the increasing importance of consumption in contemporary American society, he labelled a sort of axiology in which better living standards are assumed to be of superior value. In his opinion, consumptionism in American society could be defined as follows:

Through the centuries, the problem has been how to produce enough of the things men wanted; the problem now is how to make men want and use more than enough things - the science of plenty, it has been called ... Consumptionism is the science of compelling man to use more and more things. Consumptionism is bringing it about that the American citizen's first importance to his country is no longer that of citizen but that of consumer. (Benett \& O'Reilly 2010:5)

Thus, already in the first definition, consumptionism has been defined pejoratively, as a threat for social morality and a factor in steadily lowering the intellectual level of society.

Following a hermeneutical method adopted by many sociologists, one may match two ways of defining the consumer society: analytical and historical. The first one will consider its specific attributes, whereas the latter will be focused on its beginnings and the course of its historical process. The first category of definitions reflects two research attitudes. According to the first one, the consumer society is regarded as a manipulation of society performed by some social groups striving for their benefit. The second attitude considers the consumer society as stemming from human nature, which is described as egoistic and looking for supremacy over others. The first one may be categorised as a manipulative definition, the second as natural.

The first attitude to research is depicted by the Marxist theory, and its most famous representative is Baudrillard (1998); the second by sociological institutionalism, and its prominent exponents refer to the foundational works of Veblen (1899).

Also, in the historical definitions of the second, one may distinguish two key approaches. Firstly, there are those who refer the origin of the consumer society to the socio-economic transformation of the Western world, for instance, to the Industrial Revolution in England. Secondly, there are those who link the beginning of consumptionism with changes in the way of thinking of individuals. This is well depicted by the career of the notion of world view (Weltanschauung) (Dilthey \& Groethuysen 1991:84) and thus points to Romanticism and its accompanying concept of individualism as a substantive and anthropological source of consumer society.

The first category of the definitions may be described as political-economic, the second as psychological. The principal representative of the first category is Campbell (1987), of the second, McKendrick, Brewer and Plumb (1982).

Obviously, such classifications are merely a hermeneutical operation that facilitates interpretation of such an entangled phenomenon as the consumer society. They merely distinguish pure models. In practice, these particular ways of defining overlap, intersect and interrelate. This is the case, for instance, when we assume that definitions designating the historical origin of the consumer society in the time of Romanticism and its individualism converge with the theories which link the unfolding of consumptionism to social manipulation, using natural human instinct to achieve satisfaction and pleasure. 


\section{Manipulative analytical defining}

Manipulative definitions are clearly intelligible in the context of the Marxist image of society as a permanent class division and class struggle. Obviously, relevant here is not the dialectical development leading to social change as desired by Marx or other sociologists, such as Max Weber and Georg Simmel (Szacki 2012:436), but the depiction of social structure as consisted of two opposing components: the dominated groups and the subjugated groups (Dahrendorf 2012:41).

The principal premise of the Marxist (and post-Marxist) criticism of the consumer society is that it is a way for the dominating groups to take control over the subjugated groups. Here, of crucial importance is a lack of ability of the latter to become aware of its condition and a lack of ideology that would express their demands. The consumer society is in its nature idle, indolent and not interested in striving for social change, even despite increasing social inequalities.

The causes of this are manifold; they include, for instance, a high level of social acceptance of consumer reality.

However, according to manipulative definitions, of crucial importance seems to be an inability of societies to adopt a relevant understanding of social phenomena which, in turn, is related to the instrumentalisation of educational processes (i.e. regarding education as the training to be both a perfect worker and a consumer, instead of as the holistic development of a human person).

In this way, the consumer society was portrayed by Baudrillard (1998), who introduced this category to philosophy and the social sciences. As the motto of his brilliant analysis of the phenomenon he chose a quotation from Dostoyevsky, a sentence from his Notes from Underground that even today astonishes by its intuition of future moral collapse:

Shower him with all earthly blessings, plunge him so deep into happiness that nothing is visible but the bubbles rising to the surface of his happiness, as if it were water; give him such economic prosperity that he will have nothing left to do but sleep, eat gingerbread, and worry about the continuance of world history. (Baudrillard 1998:v)

The French sociologist admitted that the consumer society should be comprehended in terms of the class struggle. He blatantly stated that 'consumption, like the education system, is a class institution' (Baudrillard 1998:59) and explained that an apparent democratisation of consumption mirrors the apparent democratisation of education. In Western societies almost all can read and write, yet literacy skills do not mean equal or at least similar opportunities to achieve required competences. Consumption is also a dividing factor, and the division is designated by the object of consumption in two ways: either by simple economic inequalities, or by one's ability to be autonomous against commodity, in other words, by the rejection of the requirements of the consumer society.
What is the meaning of manipulation in this perspective? Baudrillard (1998) wrote that:

$[T]$ he consumer society is also the society of learning to consume, of social training in consumption. That is to say, there is a new and specific mode of socialization related to the emergence of new productive forces and the monopoly restructuring of a highproductivity economic system. (p. 81)

He therefore assumed that some groups take control over the spreading of the consumer society, dispersing its values and norms, in order to make societies more vulnerable to their decision processes in the conditions of post-industrial economy. Consumption is thus the way in which the dominating groups exercise control over the subjugated groups.

In the theory of Baudrillard, society focuses on and around consumption. Consequently, both social identity and social status reflect one's consumption potential. Since one's identity requires a self-reflective process, reducing it to the permanency of consumer choice signifies that identity becomes a reflection of the consumed objects only, an artificial projection that distorts real subjectivity. The human being begins to live in illusion, without the ability to distinguish between what is good and what is bad, what is true and what is false.

\section{Natural analytical defining}

Smith (2009) in 'The Wealth of Nations' stated that:

[C]onsumption is the sole end and purpose of all production; and the interest of the producer ought to be attended to only so far as it may be necessary for promoting that of the consumer. The maxim is so perfectly self-evident that it would be absurd to attempt to prove it. (p. 390)

It seems trivially obvious to recall the Smithian theory about the market that self-regulates and therefore applies some natural rules in social and economic life. Yet the 'natural' (meaning here appealing to human nature) approach is to be found in the works of Veblen, one of the most important exponents of consumptionism. In his famous book Theory of the Leisure Class, he introduced a category of conspicuous consumption, in his opinion the strongest force (apart from economic protection) of the undertaken economic activities. Veblen assumed that individuals strive to demonstrate their economic advantage in order to impose an impression on their spectators and consequently either to gain their respect or to induce their jealousy (Campbell 1995:37-47). Consumption is also correlated with waste. The more it is conspicuous, the more means and instruments it requires, even though they are used for pure demonstration only. When expounding the term 'conspicuous consumption', he claimed that possessing of things, even of those which are unusable, is for members of the leisure class a matter of social status and prestige. Yet it is obvious that the more one strives to demonstrate his and/or her consumption, the more will be its costs, both measurable and immeasurable. 
Therefore, conspicuous consumption reflects one's social status, and the striving for manifesting one's economic advantage is embedded in human nature. Veblen refers such a striving to the so-called 'motive of emulation, which is an innate characteristic of man' (Diggins 1999:101). He explained that this specific anthropological concept is crucial for the social system:

The motive that lies at the root of ownership is emulation; and the same motive of emulation continues active in the further development of the institutions to which it has given rise and in the development of all these features of the social structure which this institution touches. The possession of wealth confers honor; it is an invidious distinction. (Diggins 1999:102)

As a consequence of the more intensified economic growth and the opportunities it has brought about, the more numerous are those who have manifested their economic advantage. This process has moved forward to the proliferation of the values of the consumer society. Consumption has been commonly accepted as a way to reveal one's social status and further, the whole of social life has come to be organised around consumption.

On the other hand, conspicuous consumption must be regarded as destructive for social life. Since it provokes an attitude in which an individual strives to manifest his and/or her advantage over others by possessing things, it has a strong potential to be proliferated. The fight for social status derives from human nature. This brings about a vast waste of resources, time and strengths for achieving the passing moments of satisfaction which, in turn, triggers an implosion of the feeling of social community. The consumer society is thus society destroying itself. It is the society of waste.

\section{Historical definitions of consumptionism \\ Historical political-economic definitions}

In searching for the origin of the consumer society, one encounters many theories that the beginning of consumptionism refers in turn to the Italian Renaissance; or the emerging modern national state in France; or the Industrial Revolution in England; or the birth of mass society at the turn of the 19th and 20th centuries; or the rapid technological progress of 19th century. Regardless of these theories, always in their background lies the question of what is decisive in designating the singular starting point of the consumer society. After all, societies and individuals have always striven for a better life, for living in luxury, or at least in welfare. When reading various relations of feasts in Ancient Rome (for instance, the famous 'Trimalchio's Feast' $),{ }^{1}$ we are still astonished by their sophisticated luxury. Yet it does not come to our mind to think about the society of Ancient Rome as the consumer society.

1.Trimalchio's feast, described by Gaius Petronius (27-66) in the Roman "Satyricon Liber", is a comic presentation of conspicuous consumption of the Ancient Roman society and a timeless symbol of luxury.
The primary and the most important requirement for the consumer society is that it must be built on the foundations of a society which is democratic, or at least democratising. Its birth is impossible when there are any serious ideological impediments in a given society that justify economic inequalities and that do not allow for enrichment of all social strata. In a democratising society, the consumer society has an inherent potential to unfold itself and consequently the conditions making its proliferation possible.

The second important feature for the origin of the consumer society is its inherent interrelation with industrialisation and urbanisation, two decisive factors of the modern economy (obviously we have to think about the modern epoch as the one that started in the 19th century). Industrialisation paved the way to massive production. Urbanisation, since it gathered huge groups of people in a small area, facilitated a proliferation and transmission of cultural patterns, norms and values; therefore, these also related to consumption.

Those are the most important of the circumstances that moved the process of the emergence of the consumer society. of the consumer society. Highly relevant seems to be the claim of the British sociologist, Neil McKendrick, who placed the roots of consumptionism in 1690s England. McKendrick et al. (1982) state that this was the time when new axiological perspectives had been emerging, that allowed an idea of common participation of the whole society in purchasing and consuming. At that time it was unthinkable that consumption could have imploded the traditional social borders. The social division up to this time was clear and seemingly indisputable, that the rich class would consume luxury commodities whereas the poor would have the minimum necessary to survive (McKendrick et al. 1982:14). The Industrial Revolution of that time intensified social mobility both in the horizontal and the vertical perspective. This caused a creeping democratisation and made the social stratification ladder more flexible.

McKendrick et al. seem to be convincing in their concept. However, it is useful to make a small remark: the tendencies and phenomena mentioned by the British sociologist and his co-authors must be regarded as derivatives of larger tendencies and phenomena which had emerged earlier and had created a necessary background to the democratisation of consumption. The great events of the 'Long Sixteenth Century' marked a time when the modern world was born (the system world): the discovery of America, the Protestant Reformation, the axiological shift from theocentrism to anthropocentrism, and the emerging of the modern national state, to mention only a few (Robinson 2011: 723-745).

\section{Historical psychological definitions}

The last of the definitional approaches is the interpretation of Campbell (1987), who discerns the beginning of 
consumptionism in the so-called modern hedonism, which in turn emerged from Romanticism and its individualism.

It is obvious that consumptionism may be understood as a derivative of hedonism; however, Campbell explains the interrelation between both in a more complex and sophisticated way. He distinguishes between traditional and modern hedonism. The first one refers to the biological pleasures of the human body and pleasures of various social interaction: typical human activities such as eating, drinking, sex, dancing and singing, among others. Therefore, satisfaction (pleasure) is achieved by various direct and sensual experiences.

In the opinion of Campbell, this sort of hedonism was crowded out by the modern one, which is performed rather by imagined or anticipated emotions. It means that the human mind produces images which are then consumed in order to achieve satisfaction. Such hedonism is far more demanding as it requires an individual's ability to control his and/or her emotions. Campbell (1995) expressed it as follows:

Like its traditional predecessor, modern hedonism is still basically a matter of conduct being pulled along by desire for the anticipated quality of pleasure which an experience promises to yield. The contrast is considerable, however. In the first place, pleasure is sought via emotional and not merely sensory stimulation, whilst, secondly, the images which fulfil this function are either imaginatively created or modified by the individual for self-consumption, there being little reliance upon the presence of real stimuli. These two facts mean that modern hedonism tends to be covert and self-illusory; that is to say, individuals employ their imaginative and creative powers to construct mental images which they consume for the intrinsic pleasure they provide, a practice best described as day-dreaming or fantasizing. (p. 78)

The cultural epoch of Romanticism paved the way for this type of hedonism since it emphasises the individual feelings of a human being: his and/or her experience and intuition. The very essence of the concept of Campbell claims that the more an individual is able to project in his and/or her mind images, experiences or emotions that provide pleasure or satisfaction, the more 'real', sensual consumption is unsatisfactory.

Consequently, consumption will be the source of continuous disappointment when an act of consumption is being fulfilled. A consumer lives in the consumer cycle, which consists of the sequence desire-purchase-consumption (use)-disappointment-new desire (Boden \& Williams 2002: 493-512). This cycle designates the rhythm of life of the homo consumens. The consumer, in the modern hedonism, will not cease looking for new, more stimulating experiences. According to Campbell's interpretation, such a consumer spiral unfolds unceasingly, despite the significance of the turning points at the end of every consumer sequence. Contemporary hedonists, known as 'consuments' in some European countries, end one act of consumption and immediately begin another, searching for the meaning in the continuity and recurrence of the process of consumption. Therefore, the contemporary hedonist or 'consument' is an individual and autonomous creator of his and/or her dreams - a dream-artist (Boden \& Williams 2002:493-512).

The brief survey and concise typology of definitions explain the nature and meaning of consumptionism and the consumer society. It also reveals many threats brought about by this phenomenon even though they are still merely predictions. Yet the philosophical and sociological analyses highlight that these dangers are real. Consumptionism creates a figure of homo consumens, an egoistic individual, who focuses on his and/or her own pleasure and satisfaction. This provokes crises in various areas of reality. It reflects in the demographical crisis and the crisis in family, since people in the consumer society are increasingly less able to create longstanding relations, reducing others merely to objects of consumption. It weakens creativity in these societies as the activity of their members is concentrated on consumption. It also results in the ecological crisis as depicted by the images of the natural environment deluged by the tons of used consumption residues. This is blatantly expressed by the German word describing the consumer society: Wegwerfgesellschaft [throwaway society]. And finally, consumptionism brings about the crisis in anthropology since such egoistic individualism can be seen as a distortion of human nature.

\section{The anthropological error: The Christian criticism of consumptionism}

This anthropological crisis is commonly stressed in various Christian theological approaches, regardless of denomination. For instance, it dominates the teaching of Pope Francis, as may be seen, for example, in the exhortation Evangelii Gaudium from 2013, which is, on the one hand, an anthropological clarification about the joy given by the gospel and about how human beings are touched by the Word of God, and, on the other, about various contexts of and impediments in the contemporary world that distort the experience of Christian joy and happiness (Pope Francis 2013:2).

It is worthwhile noticing that in the first sentences of his text, Pope Francis explicitly indicates that consumerism is a serious obstacle for the joy given by the gospel:

The great danger in today's world, pervaded as it is by consumerism, is the desolation and anguish born of a complacent yet covetous heart, the feverish pursuit of frivolous pleasures, and a blunted conscience. (Pope Francis 2013:3)

He develops a harsh and comprehensive criticism of the consumer society in the second chapter of the exhortation, which is significantly entitled 'Amid the Crisis of Communal Commitment', where consumptionism is listed as one of the most serious challenges of today's world. A wide array of those threats is related to socio-economic phenomena, 
headed by growing social exclusion, increasing economic inequalities, the dominance of the financial system over other sectors of society, and, more picturesquely, the new idolatry of money. Pope Francis, vividly and with strong confidence, seems to emphasise that 'such an economy kills' and unfolds his thought as follows:

Just as the commandment Thou shalt not kill sets a clear limit in order to safeguard the value of human life, today we also have to say thou shalt not to an economy of exclusion and inequality. Such an economy kills. How can it be that it is not a news item when an elderly homeless person dies of exposure, but it is news when the stock market loses two points? This is a case of exclusion. Can we continue to stand by when food is thrown away while people are starving? This is a case of inequality. Today everything comes under the laws of competition and the survival of the fittest, where the powerful feed upon the powerless. As a consequence, masses of people find themselves excluded and marginalized: without work, without possibilities, without any means of escape. (p. 45)

In his famous encyclical letter 'Centesimus Annus' (1991), when considering the nature of socialism, Pope John Paul II wrote about the fundamental anthropological error (Piola 2016) and explained this philosophical assumption in the following way:

Socialism considers the individual person simply as an element, a molecule within the social organism, so that the good of the individual is completely subordinated to the functioning of the socio-economic mechanism. (pp. 107-120)

\section{Consequently, as he added:}

$[M] a n$ is thus reduced to a series of social relationships, and the concept of the person as the autonomous subject of moral decision disappears, the very subject whose decisions build the social order. (1991; see para. 13)

Shadle (2018), in his presentation of Pope John Paul II's social train of thought, summarised that:

[T]he encyclical provided a stronger defense of the free-market economy than had previous Catholic social teaching, and neoconservative Catholics saw it as a vindication of their views. Centesimus Annus also harshly condemns consumerism, however, and proposes that the state has a greater role in ensuring that the economy serves the common good than do the neoconservatives. John Paul II recognizes the essential role of human creativity and ingenuity in the economy, but balances this by emphasizing that the human person is the recipient of God's grace.

Today, Pope Francis (2013) emphasises the consequences of another anthropological error which is linked to the world view which relies on the compulsive striving for profit and economic domination. This error reflects also a sort of Nietzschean axiological revaluation of all values, illustrated by the slogan 'greed is good', from Gordon Gekko's cynical speech in the film 'Wall Street' (1987). Greed is good because it is regarded as a necessary disposition of the contemporary individual worker-consumer, a value that propels him to be more efficient and more acquisitive. Yet, when looking for it outside the dominant logic, the 'dominant interpretive discourse' (Touraine 2009:52), one must ask, where are the borders of this madness? All of us seem to be immersed in this axiologically 'probating' quest for money.

According to Pope Francis, this is exactly the meaning of anthropological error. It is an idolatry of money and consumption, which in fact is an updated modern or postmodern version of the ancient biblical worship of the 'golden calf':

The current financial crisis can make us overlook the fact that it originated in a profound human crisis: the denial of the primacy of the human person! We have created new idols. The worship of the ancient golden calf (Ex 32:1-35) has returned in a new and ruthless guise in the idolatry of money and the dictatorship of an impersonal economy lacking a truly human purpose. The worldwide crisis affecting finance and the economy lays bare their imbalances and, above all, their lack of real concern for human beings; man is reduced to one of his needs alone: consumption. (Pope Francis 2013:47)

If, for Pope John Paul II (1991), anthropological crisis meant the subjugation of human beings to a constructed idea of social order, for Pope Francis it signifies the subjugation of human beings to the axiologically unrestricted desire of pleasure, consumption and wealth. However, in both cases, it is the subjugation of human beings which is the common denominator of the anthropological crisis.

Consumptionism is both a part and a derivative of this gloomy diagnosis. Pope Francis considers it to be entangled in this idolatry of money, yet simultaneously he sees it as influencing contemporary culture. The Bishop of Rome seems to reveal a hermeneutical set of interrelations building today's social reality; firstly, human beings instrumentalise themselves, reduce themselves to a consumer good, which causes a deepening social exclusion. The Pope expresses it when writing that 'human beings are themselves considered consumer goods to be used and then discarded' (Pope Francis 2013:46); secondly, it is a human being who reduces himself and/or herself to the act of consumption: 'man is reduced to one of his needs alone: consumption' (Pope Francis 2013:46). Therefore consumptionism is simultaneously reducing us as human beings to consumption and we, as human beings, are reducing ourselves to consumption; such encompassing enclosure appears as a deep slavery, and even worse, as it is difficult for consumption to become aware of itself.

This is thus the nature of the anthropological error that is embedded in consumptionism. It brings about a slavery that is both intrinsic and external. It is intrinsic because we gradually lose our ability for coming out of the logic of consumptionism, and, consequently, the value of consumption influences our culture and our axiology. For an ordinary 'he' or 'she' who is living in today's world, it seems to be increasingly difficult to think 'differently' from the consumer culture, to look from outside at the consumer society and to understand it as a sort of modern social 'imaginery' (according to the term used by Taylor). Furthermore, there is another aspect of the intrinsic dimensions of this slavery, namely, an 
individual's inability to build his and/or her identity, since consumptionism provokes a perpetual longing for other things. Bauman (2007), one of the most prominent interpreters of the postmodern world, notes that

$[T]$ he consumerist culture is marked by a constant pressure to be someone else. Consumer markets focus on the prompt devaluation of their past offers, to clear a site in public demand for new ones to fill. They breed dissatisfaction with the products used by consumers to satisfy their needs - and they also cultivate constant disaffection with the acquired identity and the set of needs by which an identity is defined. Changing identity, discarding the past and seeking new beginnings, struggling to be born again - these are promoted by that culture as a duty disguised as a privilege. (p. 231)

Furthermore, this slavery is external because the consumer society creates its own mechanisms of inclusion and exclusion which results in social order, in which a principal rule of organisation is one's ability '... to face up to the requirements of consumer choice'? Bauman (2012) insists that consumptionism has distorted such values of the modern society as equality, tolerance, and, above all, freedom. According to him, freedom in the consumer society means the freedom of consumer choice. He depicts it picturesquely when stating:

Whether genuine or putative to the eye of the analyst, the loose, the 'associative' status of identity, the opportunity to 'shop around', to pick and shed one's 'true self', to 'be on the move', has come in present-day consumer society to signify freedom. Consumer choice is now a value in its own right; the activity of choosing matters more than what is being chosen, and the situations are praised or censured, enjoyed or resented, depending on the range of choices on display. (p. 145)

Thus, in order to experience freedom, one must be a consumer and must have a consumer capability. Yet this excludes billions unable to meet the severe requirements of consumer logic. This disturbs Pope Francis (2013), describing the present 'killing' of the socio-economic system as follows:

Today's economic mechanisms promote inordinate consumption, yet it is evident that unbridled consumerism combined with inequality proves doubly damaging to the social fabric. Inequality eventually engenders a violence which recourse to arms cannot and never will be able to resolve. (p. 50)

\section{Conclusion}

Pope Francis contributes to the criticism of consumptionism. However, he does not follow the ways of previously presented approaches. He does not confirm the Marxist logic of class struggle, nor does he appeal to the emulation instinct of the human nature as insisted by Veblen. He rather evokes the image of the 'golden calf'. In the theological perspective developed by Pope Francis, consumptionism is therefore an idolatry, a quasi-religious system which provides societies with a feeling of sense and belonging. Consequently, consumptionism may be regarded as another anthropological error, when using the notion from the encyclical letter
Centesimus Annus of Pope John Paul II (1991). The latter referred the error in anthropology to socialism as a subjugation of an individual to the social and state system, whereas Pope Francis discerns this in an axiological reduction of social values to constant distraction and constant consumption.

Nevertheless, this theological perspective confirms to a great extent the diagnosis and predictions of the 'secular' approaches. This refers mostly to the foreseen consequences of consumptionism, such as the growth of social exclusion and social idleness, which can be seriously injurious to democracy and the ecological integrity of major parts of the planet. In the light of Pope Francis' thinking, consumptionism is one of the most serious disorders and the challenge for those who take responsibility for the next generation.

\section{Acknowledgements Competing interests}

The author has declared that no competing interests exist.

\section{Author's contributions}

I declare that I am the sole author of this research article.

\section{Ethical consideration}

This article followed all ethical standards for a research without direct contact with human or animal subjects.

\section{Funding information}

The article was supported by the National Science Centre, Poland, nr 2018/31/B/HS1/01254.

\section{Data availability statement}

Data sharing is not applicable to this article as no new data were created or analysed in this study.

\section{Disclaimer}

The views and opinions expressed in this article are those of the author and do not necessarily reflect the official policy or position of any affiliated agency of the authors.

\section{References}

Baudrillard, J., 1998, The consumer society. Myths and structures, Sage, London. Bauman, Z., 2007, Consuming life, Polity Press, Cambridge.

Bauman, Z., 2012, Liquid modernity, Polity Press, Cambridge.

Benett, A. \& O'Reilly, A., 2010, Consumed: Rethinking business in the era of mindful spending, St Martin's Press, London.

Boden, S. \& Williams, S.J., 2002, 'Consumption and emotion. The romantic ethic revisited', Sociology 36(3), 493-512. https://doi.org/10.1177/003803850203600 3001

Campbell, C., 1987, The romantic ethic and the spirit of modern consumerism, Basi Blackwell, Oxford.

Campbell, C., 1995, 'A critique of Veblen's theory of conspicuous consumption', Sociological Theory 13(1), 37-47. https://doi.org/10.2307/202004

Dahrendorf, R., 2012, Klasy i konflikt klasowy w społeczeństwie przemysłowym, Zakład Wydawniczy NOMOS, Kraków. 
Diggins, J.P., 1999, Thorstein Veblen: Theorist of the leisure class, Princeton University Press, Princeton, NJ.

Dilthey, W. \& Groethuysen, B., 1991, Weltanschauungslehre. Abhandlungen zur Philosophie der Philosophie, Vandenhoeck \& Ruprecht, Göttingen.

Firat, F.A., 2017, 'Marx, commodity and consumer culture', in S. Askegaard \& B. Heilbrunn (eds.), Canonical authors in consumer theory, pp. 21-29, Routledge, London.

McKendrick, N., Brewer, J. \& Plumb, J.H., 1982, The birth of the consumer society. The commercialization of the eighteen-century England, Europa Publications, London.

Piola, A., 2016, 'There can be no ecology without an adequate anthropology (LS 118). Which man can take care of our common home', Studia Koszalińsko-Kołobrzeskie 23, 107-120. https://doi.org/10.18276/skk.2016.23-06

Pope Francis, 2013, Evangelii Gaudium. Apostolic exhortation on the proclamation of the Gospel in today's world, Veritas, Dublin.

Pope John Paul II, 1991, Centesimus Annus. Encyclical letter on the hundredth anniversary of Rerum Novarum, Pauline Book and Media, Boston, MA.
Robinson, W.I., 2011, 'Globalization and the sociology of Immanuel Wallerstein: A critical appraisal', International Sociology 1(23), 723-745. https://doi. org/10.1177/0268580910393372

Sagoff, M., 1998, 'Carrying capacity and ecological economics', in D.A. Crocker \& T. Linden (eds.), Ethics of consumption. The good life, justice and global stewardship, pp. 29-52, Rowman and Littlefield Publishers, Oxford.

Shadle, M.A., 2018, Interrupting capitalism. Catholic social thought and the economy, Oxford University Press, Oxford.

Smith, A., 2009, An inquiry into the nature and causes of the wealth of nations, Digireads Publishing, New York, NY.

Szacki, J., 2012, Historia myśli socjologicznej, Wydawnictwo Naukowe PWN, Warszawa.

Touraine, A., 2009, Thinking differently, Polity Press, Cambridge.

Veblen, T., 1899, The theory of the leisure class: An economic study in the evolution of institutions, Macmillan, New York.

Weiser, S., Stone, O., 1987, Wall Street, a film, directed by Oliver Stone, produced by American Entertainment. 